\title{
Editorial
}

\section{A ESCOLA DE ENFERMAGEM ANA NÉRI COMEMORA SEUS CINQÜENTA ANOS À SERVIÇO DA COMUNIDADE BRASILEIRA}

O cinquentenário da Escola de Enfermagem da Universidade Federal do Rio de Janeiro, ainda hoje conhecida como Escola Ana Neri, leva-nos a recorrer alguns fatos relacionados com sua fundação, sua missão histórica e o importante papel que tem desempenhado no cenário da enfermagem no Brasil.

Embora não fosse a primeira a ser fundada - outras haviam sido criadas anteriomente - foi a Escola Ana Neri a primeira a ser estruturada segundo modernos padrões do ensino da enfermagem.

Em 1920, quando um grupo de sanitaristas percebeu que a colaboração de enfermeiras de saúde pública seria imprescindivel para a consecução dos objetivos da reforma realizada no Departamento Naciona! de Saúde, a criação de uma escola para a formação desses profissionais tornou-se imperativa. O prof. Carlos Chagas, então Diretor do Departamento, em nome do Governo brasileiro, dirigiu-se à Fundação Rockfeller solicitando-lhe cooperação para a fundação de uma escola de enfermagem.

Atendida a solicitação, chegou ao Rio de Janeiro em 1921 Ethel Parsons, enfermeira norte-americana, a fim de verificar se as condições existentes permitiam a realização do projeto.

O conhecimento das condições sociais apresentadas pelo país, no início da decada e 20, deixou Ethel Parsons cética a respeito do $€$ mpreendimento. Realmente, o então Distrito Federal, com uma população estimada em 1.200 .000 habitantes, apresentava taxa de analfabetismo de 25,8., correspondente a pessoas maiores de 15 anos, das quais o número de elementos do sexo feminino era consideravelmente maior do que o dos homens. Igualmente era limitadissimo o número de moças portadoras de certificado de curso secundário. Ademais, poucos eram os médicos familiarizados com 0 trabalho que desempenhavam as enfermeiras diplomadas nos Estados Unidos, 
Canadá e em alguns países europeus. Em um de seus relatórios, Ethel Parsons indicou não ser exagerada a afirmação de que os brasileiros, em geral consideravam o exercício da enfemagem da mesma maneira que os ingleses o consideravam em meados do do século XIX, antes da reforma de Florence Nightingale.

Não fôra o apoio e o estímulo que recebeu dos sanitaristas do Departamento Nacional de Saúde Pública, que conheciam a atuaçãn das enfermeiras no campo de saúde nos Estados Unidos, é bem possível que a educadora norte-americana não tivesse recomendado a criação de uma escola de enfermagem, pelo menos naquele decênio.

Felizmente, para todos nós, a recomendação foi feita. E aqui temos a Escola Ana Neri, a antiga Escola de Enfermagem do Departamento Nacional de Saúde Pública, festejando meio século de existência.

Desde o início, Carlos Chagas insistiu sobre o alto nível de ensino a ser ministrado no curso de enfermagem. Parece-nos que a aspiração de Ethel Parsons era organizar uma escola de nível superior. Influenciada certamente pelo Relatório Goldmark - estudo sobre a educação da enfermagem nos Estados Unidos, realizado no começo da década de 20 - que recomendava a criação de escolas de enfermagem em nível superior, é natural que Ethel Parsons quizesse que nova Escola fosse reflexo das modernas idéias sobre o ensino da enfermagem. O diploma da escola normal, como exigência para a matrícula, conforme as determinações do Decreto n. ${ }^{\circ}$ 16.300, de 1923, que criava a Escola, revela claramente essa aspiração. Todavia, prevendo as dificuldades de recrutamento em face Ge tal exigência e conhecedoras da realidade brasileira, os sanitaristas do Departamento tomaram uma sábia medida: para aquelas que não fossem normalistas, a apresentação de documento que provasse ter a candidata "instrução secundária bastante", a critério da diretora, seria suficiente para a admissão à Escola.

Novamente, em 1931, nos "considerando" do Decreto Federal n..$^{\circ}$ 20.109, que regula o exercício da enfermagem e fixa as condiçōes para a equiparação das escolas de enfermagem transparece a aspiração de Ethel Parsons de integrar a Escola Ana Neri em Universidades do Brasil. E, mais uma vez, a concretização dessa aspiração foi postergada.

Somente em 1945, quase 20 anos após sua fundação, foi a Escola Ana Neri incluida como estabelecimento de ensino superior na 
Universidade. Se hoje a Escola Ana Neri goza das prerrogativas de uma unidade da Universidade Federal do Rio de Janeiro, essa situação nada mais é que o pleno desenvolvimento do germe contido na semente lançada há meio século

Nesses 5 decênios de vida, foram fecundas as atividades da Escola, quar no plano educacional quer no de serviços prestados à comunidade. Como primeiro centro de formação profissional, é comparável à Escola de St Thomaz, fundada em Londres por Florence Nightingale. Nas décadas de 20 e 30 e mesmo na de 40 , suas enfermeiras foram as únicas a ocupar as posições chave nos serviços de saúde pública de capitais de muitos estados da União; foram elas que fundaram escolas de enfermagem e reorganizaram o serviço de enfermagem dos modernos hospitais de ensino.

Nesses 50 anos de existência, tanto as enfermeiras norte-americanas, que dirigiam a escola no período inicial, como as brasileiras que lhes sucederam muito se empenharam para o continuo progresso da instituição. Além do curso de graduação, preocuparamse com ensino de enfermagem em outros níveis. O curso de auxiliares de enfermagem, mantido durante anos, e o atual curso colegial de enfermagem denotam o empenho em contribuir para a formação de pessoal técnico para os serviços de saúde. No ano passado, com a instalação do curso pós graduação, em nível de mestrado, novamente demonstrou a Escola seu zelo e interesse pelo progresso de educação da enfermagem.

Ao escrever estas notas, não tivemos a intenção de apresentar o histórico, mesmo sucinto, da Escola Ana Neri. Como foi mencionado no início, quizemos somente relembrar alguns pontos altos de sua história que a nova geração de enfermeiras precisa conhecer, a fim de poder admirar todos aqueles que muito deram para colocar a enfermagem no plano em que hoje se encontra.

E, para finalizar, não poderiamos omitir a contribuição valiosa da Escola na organização de nossa associação de classe e na fundaçāo da revista, órgão oficial da entidade. Em 1926, um pequeno grupo de suas enfermeiras recém formadas fundaram a Associação Nacional de Enfermeiras Diplomadas Brasileiras, posteriormente denominada Associação Brasileira de Enfermeiras Diplomadas e, hoje, Associação Brasileira de Enfermagem (ABEn). Alguns anos depois, em 1932 foi fundada a revista "Anais de Enfermagem" cujo 
primeiro número foi publicado em 1932. A partir de 1955, a publicação passou a denominar-se Revista Brasileira de Enfermagem. (RBEn).

A Associação e a Revista desenvolveram lentamente, acompanhando, como é natural, o rítmo de crescimento da profissão. E longe está o passado em que ambas surgiram sob os auspícios da Escola Ana Neri.

Nesta data festiva, em que se iniciam as comemorações do ano de seu cinquentenário, em nome das enfermeiras brasileiras, queremos apresentar congratulações a esta Escola e expressar nossa gratidão pelo muito que tem feito para o desenvolvimento da profissão. 